\title{
The Search for Dietary Supplements to Elevate or Activate Circulating Paraoxonases
}

\author{
José M. Lou-Bonafonte ${ }^{1,2,3,4}$, Clara Gabás-Rivera ${ }^{4,5}$, María A. Navarro ${ }^{2,3,4,5}$ \\ and Jesús Osada $2,3,4,5, *$ \\ 1 Departamento de Farmacología y Fisiología, Facultad de Ciencias de la Salud y del Deporte, \\ Huesca E-22002, Spain; mlou@unizar.es \\ 2 Instituto de Investigación Sanitaria de Aragón, Universidad de Zaragoza, Zaragoza E-50009, Spain; \\ angelesn@unizar.es \\ 3 Instituto Agroalimentario de Aragón, Centro de Investigación y Tecnología Agroalimentaria, \\ Universidad de Zaragoza, Zaragoza E-50013, Spain \\ 4 Centro de Investigación Biomédica en Red de Fisiopatología de la Obesidad y Nutrición, \\ Instituto de Salud Carlos III, Madrid E-28029, Spain; clarisgr_@hotmail.com \\ 5 Departamento de Bioquímica y Biología Molecular y Celular, Facultad de Veterinaria, \\ Zaragoza E-50013, Spain \\ * Correspondence: josada@unizar.es; Tel.: +34-976-761-644; Fax: +34-976-761-612
}

Academic Editor: Maurizio Battino

Received: 15 December 2016; Accepted: 10 February 2017; Published: 15 February 2017

\begin{abstract}
Low levels of paraoxonase 1 (PON1) have been associated with the development of several pathological conditions, whereas high levels have been shown to be anti-atherosclerotic in mouse models. These findings suggest that PON1 could be a good surrogate biomarker. The other members of the family, namely PON2 and PON3, the role of which has been much less studied, deserve more attention. This paper provides a systematic review of current evidence concerning dietary supplements in that regard. Preliminary studies indicate that the response to dietary supplements may have a nutrigenetic aspect that will need to be considered in large population studies or in clinical trials. A wide range of plant preparations have been found to have a positive action, with pomegranate and some of its components being the best characterized and Aronia melanocarpa one of the most active. Flavonoids are found in the composition of all active extracts, with catechins and genistein being the most promising agents for increasing PON1 activity. However, some caveats regarding the dose, length of treatment, bioavailability, and stability of these compounds in formulations still need to be addressed. Once these issues have been resolved, these compounds could be included as nutraceuticals and functional foods capable of increasing PON1 activity, thereby helping with the long-term prevention of atherosclerosis and other chronic ailments.
\end{abstract}

Keywords: paraoxonase 1; paraoxonase 2; catechins; genistein; plant extracts; atherosclerosis

\section{Introduction}

Atherosclerosis is a chronic disorder of the arterial wall that starts with the formation of fatty streaks and gradually evolves into atherosclerotic plaques [1]. Blood high-density lipoprotein (HDL) levels are inversely correlated with atherosclerosis [2], with this beneficial effect of HDL being partly attributed to its antioxidant properties mediated by paraoxonase 1 (PON1) [3,4] or platelet-activating factor acetylhydrolase (PAF-AH) [5].

The PON1 gene, together with the genes for paraoxonases 2 and 3, form a gene family located on the long arm of human chromosome 7 (7q21-22). PON1 is synthesized in the liver and secreted into the serum as an HDL-associated protein [6]. As an antioxidant enzyme carried by HDL, it can 
hydrolyze lipid peroxide in lipoproteins as a result of its lipolactonase activity (Figure 1) [7,8], thereby decreasing oxidative stress in serum lipoproteins, macrophages, and atherosclerotic lesions.
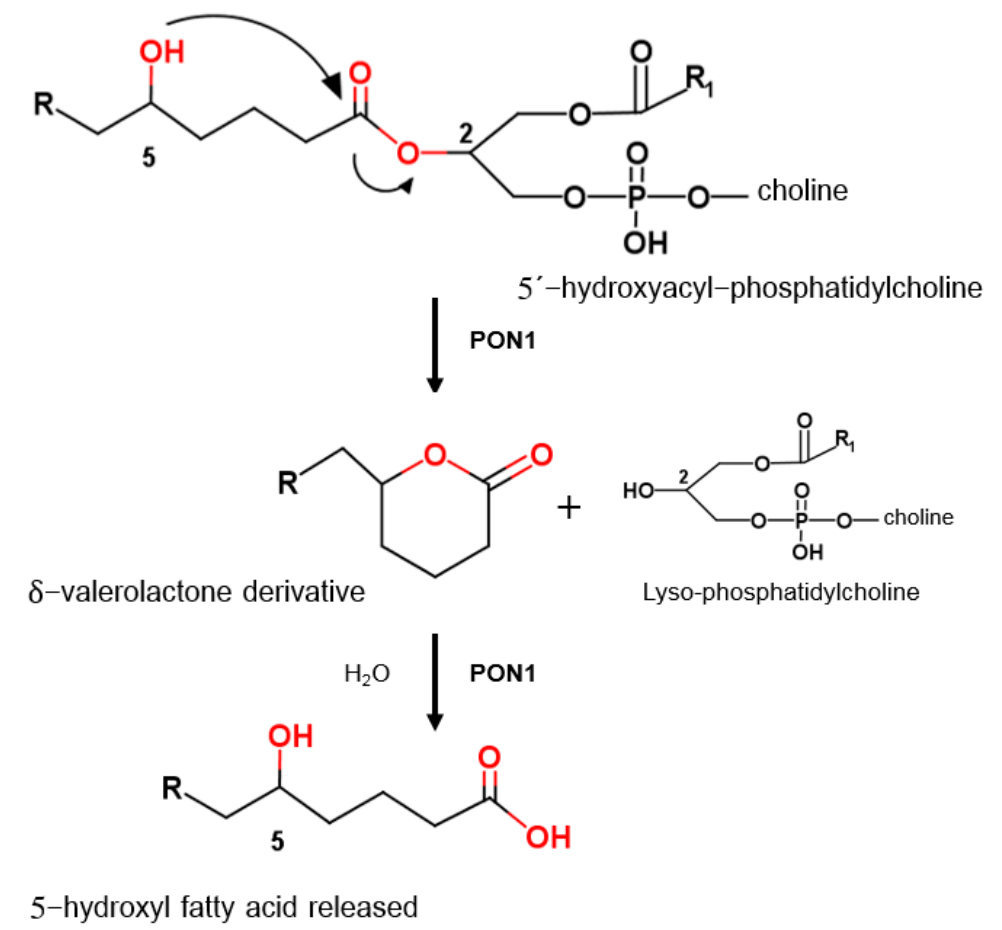

Figure 1. Proposed biological role of paraoxonase 1. Adapted from [7], reproduced with permission from the American Society for Biochemistry and Molecular Biology. Although 5-hydroxy fatty acids are not frequent in normal physiology, they appear during inflammatory processes in macrophages and dendritic cells due to the action of cytochromes P-450 and 5'-lipooxygenase [9]. The extent to which they can esterify to form phosphatidylcholine is unknown.

In light of the above, PON1 could be partly responsible for the anti-inflammatory and antiatherogenic properties of HDL molecules in blood [10]. Serum PON1 activity has been inversely associated with the risk of cardiovascular disease [11] and has been found to be decreased in several situations associated with atherosclerosis and oxidative stress [12]. Direct proof of its effects on atherosclerosis development was obtained from Pon1-deficient mice [13] and their counterparts overexpressing human PON1 gene [14]. As such, PON1 plays a major role in the protective role of HDL, and its status is considered to be one of the determinants that predispose people to coronary artery and other diseases [12]. Since PON1 undergoes inactivation by oxidative stress, its activity needs to be preserved [10]. Given the panoply of positive actions of PON1, pharmacological and nutritional modulation of PON1 activity and/or gene expression could constitute a useful approach to the prevention of cardiovascular and other diseases, such as diabetes, Alzheimer's disease, chronic renal failure, and chronic liver impairment [15]. A recent review concerning PON1 and the Mediterranean diet analyzed the impact of this diet [16]. Dietary supplements also represent a new approach to enhancing population-based health [17]. In this work, we have searched for evidence of the effect of dietary supplements and plant extracts on PON1 by way of a strategy following systematic review guidelines [18]. As displayed in Figure 2, a search in PubMed using the keywords (paraoxonase and dietary supplements and paraoxonase and plant extracts), or ("aryldialkylphosphatase" [Mesh]) AND ("Plant Extracts" [Mesh] OR "Dietary Supplements" [Mesh]) identified 172 hits between November 1945 and 04 October 2016. The search was refined by eliminating duplicate documents. The 94 papers obtained were critically reviewed to verify whether they analyzed PON1 and dietary administration. 
Documents that failed to meet this criterion were excluded. Thus, this review covers the studies related to the effects of dietary supplements and PON1 published in 90 papers.

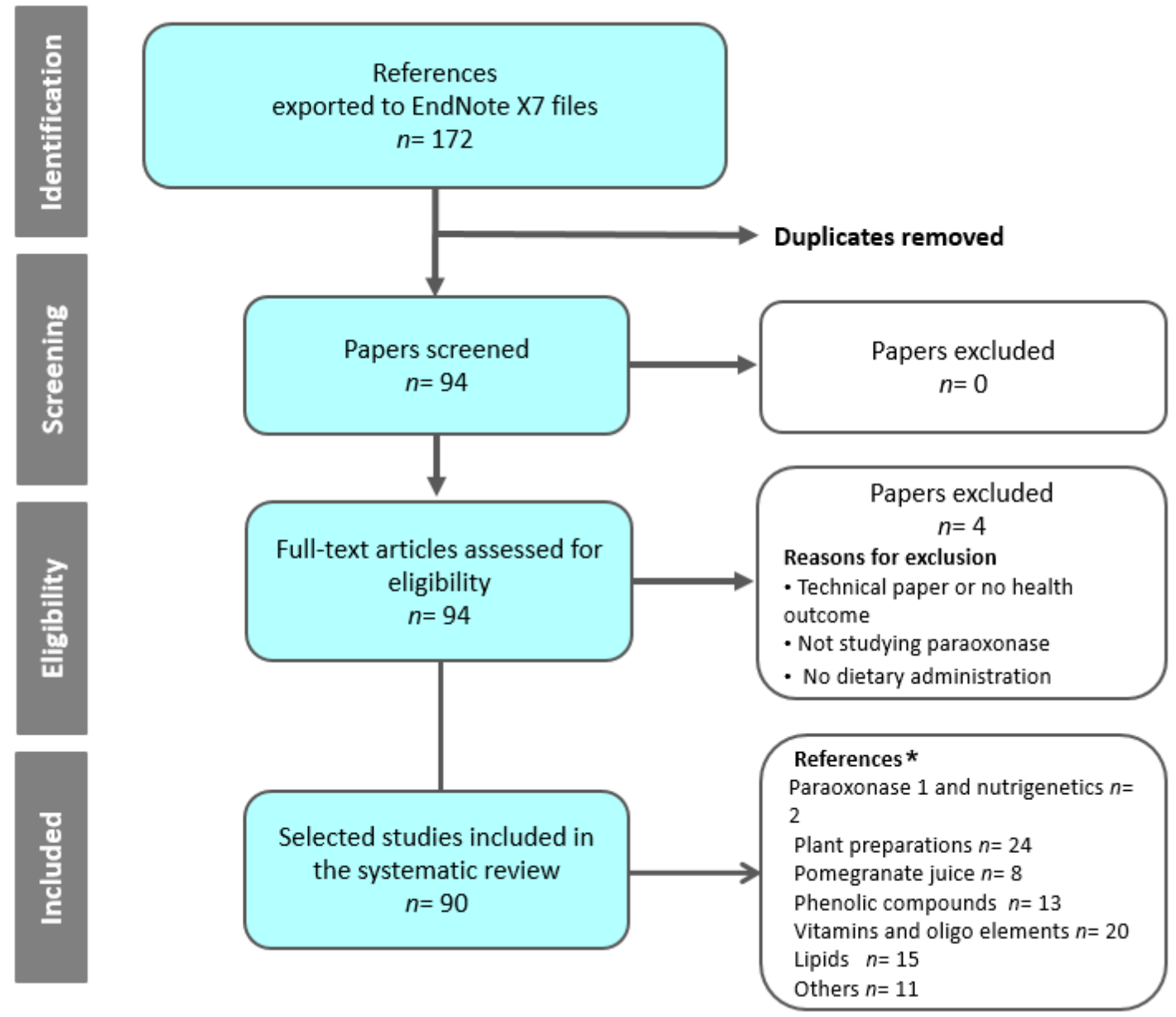

Figure 2. Flow chart displaying the steps followed to select the references considered. EndNote $\mathrm{X} 7$ (Thomson Reuters: New York, NY, USA, 2016). * Some references may appear in more than one section of the review.

\section{PON1 and Nutrigenetics}

The interindividual variation in the response of PON1 activity to dietary supplements is partly influenced by genetic factors, such as polymorphisms in the APOE or PON1 genes, as indicated by two experimental studies. In the first study, administration of a diet containing $2 \mathrm{~g} / \mathrm{kg}$ quercetin for six weeks resulted in lower hepatic mRNA and protein levels of PON1 in APOE4 than in APOE3 transgenic mice. These results indicate that PON1 is differentially regulated in response to the APOE genotype [19]. The second study had a cross-over design and was intended to determine the effect of $250 \mathrm{~mL}$ of antioxidant-rich orange plus $250 \mathrm{~mL}$ of blackcurrant juice and $15 \mathrm{mg}$ vitamin $\mathrm{E}$ supplement for 28 days on PON1 activity, although no changes were observed in patients with peripheral arterial disease. However, a gene-diet interaction was observed between dietary treatment and the PON1 genotype, with PON1 activity increasing after consumption of juices alone in patients carrying the PON1L55 allele [20].

\section{Plant Preparations}

A great deal of experimental work has been carried out on the effect of different plants on PON1, with a large variety of models also having been tested. In this regard, mice and rats are the most widely 
used models for testing the effect of plant extracts. For example, Eucommia ulmoides Oliver leaf extract equivalent to $1 \%$ dried whole leaf $(1.87 \mathrm{~g}$ of extract $/ \mathrm{kg}$ of diet) was administered for six weeks to type 2 diabetic C57BL/KsJ-db/db mice. This extract elevated plasma PON1 activity compared with the control group [21]. A similar effect was observed by Saha et al., who reported that PON1 activity in serum and liver increased after administration of an aqueous Murraya koenigii extract at doses of 75 and $150 \mathrm{mg} / \mathrm{kg}$ body weight in streptozotocin-induced diabetic mice [22]. Likewise, supplementation of grape seed extracts recovered the decreased PON1 activity found in streptozotocin-induced diabetic rats [23]. In contrast, El-Beshbishy et al. did not find recovery of PON1 activity upon administration of a daily dose of $500 \mathrm{mg} / \mathrm{kg}$ of ethanolic extracts from Morus alba L. (Egyptian mulberry) root bark in hypercholesterolemic rats [24].

Red wine polyphenol extract supplementation to the drinking water of heterozygous $\mathrm{Cbs}$-deficient mice (a murine model of hyperhomocysteinemia) for four weeks increased hepatic Pon 1 expression and hepatic and plasma PON1 arylesterase activities [25]. Administration of a $1.25 \%(w / w)$ anthocyanin-rich extract from black elderberry (Sambucus nigra, 13\% anthocyanins) containing cyanidin 3 -sambubioside and cyanidin 3-glucoside $(9.8 \%$ and $3.8 \%, w / w$, respectively) significantly increased serum PON1 arylesterase activity in 10-week-old male Apoe-deficient mice after six weeks [26]. In this model, $0.05 \%$ dietary Chokeberry extract was also found to increase serum PON1 activity [27]. According to an analysis of doses used and the magnitude of the observed effect reflected in Table 1, the Aronia melanocarpa (chokeberry) extract was the most effective at increasing PON1 activity. It has been proposed that the phenolic compounds contained therein, especially anthocyanins, phenolic acids, proanthocyanidins, and flavonols, might be involved in this effect.

When Jaiswal et al. explored the effect of onion extract and flavonoids (quercetin and catechin) on the regulation of PON1 expression in male Wistar rats subjected to mercuric chloride-induced oxidative insult, they observed that onion extract significantly attenuated the adverse effects of $\mathrm{HgCl}_{2}$ by upregulating PON1 activity. Quercetin and, to a lesser extent, catechin induced similar effects [28]. In this animal model, the administration of Aronia melanocarpa juice statistically restored the PON activity of rats on a high-fructose and unsaturated fat diet [29]. Cornelian cherry, as a rich source of phenolic compounds, had a stimulating effect on PON1 activity in both the brain tissue and plasma of Wistar rats consuming control, high-fructose, and high-fat diets [30]. In rats with myocardial ischemia, treatment with flaxseed in combination with exercise recovered the decreased PON1 and HDL levels, whereas administration of flaxseed alone had no effect [31]. In a rat ischemia-reperfusion model, significant decreases were observed in the serum PON1 levels of animals given ginsenoside despite the decrease in malonyldialdehyde [32]. In contrast, the decrease of PON1 and arylesterase activities in arthritis-induced rats was restored after treatment with soy protein and isoflavone (genistein and daidzein) for 50 days [33]. Likewise, 2\% (dry $w / w)$ diet supplementation with pulp of Euterpe oleracea Mart also increased PON1 activity in female Fischer rats fed standard chow (AIN-93 M) or hypercholesterolemic ( $25 \%$ soy oil and $1 \%$ cholesterol) diets [34]. The inclusion of $28 \%$ avocado in the diet increased PON1 activity in Wistar male rats [35].

Supplementation of the ethyl acetate extract of Vigna unguiculata leaves ( $150 \mathrm{mg} / \mathrm{kg}$ body weight) normalized the decreased PON1 expression of rabbits fed a diet containing $1 \%$ cholesterol and $0.5 \%$ cholic acid [36]. 
Table 1. Plant preparations found to increase serum PON1 in different experimental designs.

\begin{tabular}{|c|c|c|c|c|}
\hline Extract & Experimental Model & Dose & Effect & References \\
\hline Eucommia ulmoides Oliver leaf & Diabetic C57BL/KsJ-db/db mice & $400 \mathrm{mg} / \mathrm{kg} \mathrm{bw}$ & $\uparrow 22 \%$ & [21] \\
\hline Murraya koenigii & Streptozotocin-induced diabetic mice & $150 \mathrm{mg} / \mathrm{kg}$ & $\uparrow 105 \%$ & {$[22]$} \\
\hline Grape seed extracts & Streptozotocin-induced diabetic rats & $100 \mathrm{mg} / \mathrm{kg}$ & $\uparrow 86 \%$ & [23] \\
\hline Red wine polyphenol extract & Heterozygous Cbs-deficient mice & $100 \mathrm{mg} / \mathrm{kg}$ & $\uparrow 20 \%$ & [25] \\
\hline Sambucus nigra & Apoe-deficient mice & $200 \mathrm{mg} / \mathrm{kg}$ & $\uparrow 20 \%$ & [26] \\
\hline Aronia melanocarpa & Apoe-deficient mice & $6 \mathrm{mg} / \mathrm{kg}$ & $\uparrow 39 \%$ & {$[27]$} \\
\hline Onion extract & Mercuric chloride-induced oxidative insult in male Wistar rats & $20 \mathrm{mg} / \mathrm{kg}$ & $\uparrow 30 \%$ & [28] \\
\hline Aronia melanocarpa & Rats on a high-fructose and high-fat diet & Not reported & $\uparrow 65 \%$ & [29] \\
\hline Cornelian cherry & Rats on a high-fructose and high-fat diets & Not reported & $\uparrow 45 \%$ & {$[30]$} \\
\hline Genistein & Arthritic rats & $20 \mathrm{mg} / \mathrm{kg}$ & $\uparrow 230 \%$ & [33] \\
\hline Euterpe oleracea Mart & Female Fischer rats on high-cholesterol, high-fat diets & $2 \mathrm{mg} / \mathrm{kg}$ & $\uparrow 60 \%$ & [34] \\
\hline Avocado & Male Wistar rats & $28 \mathrm{~g} / \mathrm{kg}$ & $\uparrow 33 \%$ & [35] \\
\hline Ilex paraguariensis & Healthy volunteers & $0.5 \mathrm{~L}$ of extract & $\uparrow 10 \%$ & {$[37]$} \\
\hline Cranberry extract with vitamin $C$ and zinc & Healthy volunteers & $2 \mathrm{~g} /$ day (300 mg/day) & $\uparrow 67 \%$ & [38] \\
\hline Zingiber officinale & Type 2 diabetic patients & $3 \mathrm{~g}$ & $\uparrow 28 \%$ & [39] \\
\hline Salvia miltiorrhiza & Type 2 diabetic patients & Not reported & Increased PON1 activity & {$[40]$} \\
\hline Origanum onites & Hyperlipidemic patients & Not reported & $\uparrow 14 \%$ & [41] \\
\hline
\end{tabular}


The influence of several compounds has been investigated in both human cell lines and human subjects. In the former, HepG2 cells were treated with various concentrations of Graptopetalum paraguayense extracts for $48 \mathrm{~h}$, with those extracts prepared in $50 \%$ ethanol in water being found to be the most effective at increasing PON1 arylesterase activity and gene expression [42]. In the latter approach, PON1 activity was considered as a marker of antioxidant protection. In this regard, administration of $0.5 \mathrm{~L}$ of Ilex paraguariensis extract $(2-20 \mu \mathrm{L} / \mathrm{mL})$, the polyphenol-rich beverage mate, to healthy volunteers resulted in increased PON1 activity [37]. This action could be due to 5-caffeoylquinic acid, which is the main compound in coffee, many fruits, and Ilex paraguariensis extracts, which showed a concentration-dependent inhibition of HDL oxidation that was complete at $25 \mu \mathrm{mol} / \mathrm{L}$ [43]. Begcevic et al. found that administration of cranberry extract ( $2 \mathrm{~g} /$ day) and vitamin $\mathrm{C}$ plus zinc (300 mg/day) to 31 healthy volunteers for four weeks induced a significant increase in PON1 activity in nonsmokers [38]. However, the administration of $300 \mathrm{mg} /$ day of phenolic compounds obtained from French oak wood (Quercus robur) had no significant influence on glutathione levels and PON1 activities towards either arylester or lactone substrates despite a significant negative correlation between paraoxonase lactonase activity and homocysteine levels in 20 healthy volunteers [44]

Ginger (Zingiber officinale) has been shown to contain biologically active compounds, including gingerol, shogaol, paradol, and zingerone. In a double-blind, placebo-controlled, randomized clinical trial, supplementation of $3 \mathrm{~g}$ of powdered ginger for three months improved PON1 activity in patients with type 2 diabetes [39]. In this type of patients, a hydrophilic extract of Salvia miltiorrhiza administered for 60 days also increased PON1 activity and the latter was accompanied by a decrease in oxidative stress [40]. In mild hyperlipidemic patients, consumption of Origanum onites distillate significantly increased serum paraoxonase and arylesterase activities and improved endothelial function [41]. These observations point to the potential complementary role of dietary supplements in improving PON1 and their possible introduction into primary prevention of atherosclerosis. Moreover, the disparity of experimental settings indicates that more comprehensive studies are required to establish the protective effect of different plant preparations and limitations in terms of doses or pre-existing pathological damage.

\section{Pomegranate Juice}

Pomegranate juice contains tannins and anthocyanins, some of which, including punicalagin, punicalain, gallic acid, and urolithins A and B, are very powerful antioxidants [45]. For this reason, the effects of pomegranate juice have been widely studied in a range of experimental settings [46-50]. As such, a special section will be devoted to this juice.

In patients with carotid artery stenosis, pomegranate juice consumption for a period of 12 months resulted in an $83 \%$ increase in serum PON1 activity, together with a reduction in common carotid intima-media thickness and systolic blood pressure. No further benefit was observed when a longer administration regimen was followed [46]. Pomegranate juice consumption by diabetic patients resulted in anti-oxidative effects on serum and macrophages, with an increase in PON1 activity that reached the values found for normal subjects. These effects could contribute to an attenuation of atherosclerosis development in these patients [47]. In diabetic patients, HDL-associated PON1 arylesterase, paraoxonase, and lactonase activity increased significantly after consumption of Wonderful brand pomegranate juice $(50 \mathrm{~mL} /$ day for four weeks). PON1 protein binding to HDL was significantly increased, and the enzyme became more stable. A similar pattern was observed in both male and female patients who consumed pomegranate polyphenol extract $(5 \mathrm{~mL} /$ day for six weeks), although to a lesser degree in the latter [51]. A higher dose (10 mL/day) pomegranate extract for 12 weeks was found to increase PON1 in patients with active rheumatoid arthritis [48]. In hemodialyzed patients, daily administration of $1000 \mathrm{mg}$ of a purified pomegranate polyphenol extract for six months increased PON1 activity [52]. Pomegranate juice, or its purified phenolic compounds punicalagin, gallic acid, or ellagic acid, promote binding of a labeled recombinant PON1 to HDL 
in vitro [49]. Since the association of PON1 with high-density lipoprotein (HDL) stabilizes the enzyme, these beneficial effects of pomegranate consumption on serum PON1 stability and activity could lead to retardation of atherosclerosis. Pomegranate extracts administered to Apo-E deficient mice increased serum PON1 activity, with whole fruit juice being more efficient than administration of aryls [50].

This extract has also been combined with others to improve its properties. Thus, the combination of pomegranate with date extract, which is also a good source of phenolic compounds, has been tested in Apoe-deficient mice. At a dose of $0.5 \mu \mathrm{mol} /$ day /mouse of gallic acid equivalents, pomegranate juice, Hallawi date extract, date seed extract, or a combination of them were tested for three weeks. Consumption of the combination resulted in the highest increases in serum and aorta PON1 activities, the latter of which was associated with a reduction in aortic lipid peroxide content [45].

\section{Phenolic Compounds}

Cinnamate is a widespread secondary metabolite of phenolic compounds synthesized by plants. When two structurally related derivatives, namely 4-hydroxycinnamate and 3-(4-hydroxyphenyl) propionic acid, were administered at a dose of $1.35 \mathrm{mmol} / \mathrm{kg}$ to male rats fed a high-cholesterol diet, plasma PON1 activity was found to be higher in the cinnamate-derivative-supplemented groups than in the control group [53].

Curcumin is a common dietary supplement that has been shown to induce PON1 transactivation in Huh7 cells in a dose-dependent manner. However, dietary supplementation of female B6C3F1 mice with curcumin ( $500 \mathrm{mg} / \mathrm{kg}$ diet) for two weeks did not increase hepatic Pon $1 \mathrm{mRNA}$ and protein levels. In conclusion, curcumin may be a potent PON1 inducer in cultured cells in vitro, but not in the liver of curcumin-fed mice because of its low concentrations in vivo [54]. This low bioavailability could be due to its chemical instability at the extreme $\mathrm{pH}$ values found in the stomach and intestine.

Resveratrol is one of the best-studied phenolic compounds found in red wine, and its influence has been tested in vitro and in vivo. Thus, incubation of HUH7 liver cells stably transfected with PON1 in the presence of 10 and $25 \mu \mathrm{mol} / \mathrm{L}$ resveratrol significantly increased PON1 transactivation. An ascorbic acid concentration of $1000 \mu \mathrm{mol} / \mathrm{L}$ slightly enhanced PON1 transactivation. Furthermore, resveratrol induces PON1 protein levels in HUH7 cells, and this induction was not counteracted by ascorbic acid [55].

To investigate the anti-atherogenic properties of resveratrol supplements $(0.02 \%$ and $0.06 \%, w / w)$, Apoe-deficient mice were used. Plasma PON activity was significantly higher in the group receiving $0.06 \%$ resveratrol compared to the control group, as was HDL concentration and the HDL/total cholesterol ratio. Moreover, PON1 activity was negatively correlated with serum thiobarbituric acid reactive substances (TBARS) concentration [56]. Resveratrol showed a different pattern in cystathionine beta synthase-deficient mice, with a one-month administration of $0.001 \%$ resveratrol significantly decreasing serum PON1 activity [57].

Several epidemiological studies have reported that consumption of flavonoids, which are polyphenolic compounds available in plant-based foods, and especially catechins, might have a chemopreventive effect against cancer and cardiovascular disease [58]. Given these findings, their effect on PON1 has also been tested. Thus, supplementation with naringenin, or its synthetic derivative naringenin 7-O-cetyl ether $(0.73 \mathrm{mmol} / \mathrm{kg}$ diet $)$, increased plasma PON1 activity in high-cholesterol-fed male Sprague-Dawley rats [59]. In male Wistar rats receiving a $400 \mathrm{mg} / \mathrm{kg}$ dose of rutin for two weeks, the hepatic activity of PON1 increased by $17 \%$ compared to controls [60]. In this animal model, Jaiswal et al. showed that administration of quercetin, and to a lesser extent catechin, significantly attenuated the adverse effects of $\mathrm{HgCl}_{2}$ by upregulating PON1 activity and protected against LDL oxidation and lipid peroxidation [28]. A similar result was found by Mohammadshahi et al., who also observed a recovery in the decreased PON1 activity in arthritic rats when administering soy isoflavones (genistein and daidzein) for 50 days [33]. In hemodialyzed patients receiving catechins (455 mg/day), PON1 activity was higher than in patients with the placebo [61]. 
Genistein was the most potent flavonoid in terms of PON1-inducing activity in stably transfected Huh7 liver cells in comparison with other flavonoids. In contrast, dietary genistein supplementation ( $2 \mathrm{~g} / \mathrm{kg}$ diet over three weeks) in growing rats did not increase hepatic Pon $1 \mathrm{mRNA}$ and protein levels or plasma PON1 activity. Thus, genistein may be a PON1 inducer in cultured hepatocytes in vitro, but not in rats in vivo [62]. Plasma PON1 activity did not change after genistein was combined with polysaccharide supplementation in postmenopausal Korean women. However, the activity of other antioxidant enzymes, such as glutathione peroxidase, was significantly increased. These findings suggest that this supplementation may improve antioxidant status in postmenopausal women, but not in a PON1-dependent manner [63]. Due to the metabolism of these compounds by intestinal microbiota, a wide range of biological responses associated with different microbiomes is to be expected. Thud, daidzein may be transformed into equol, an isoflavandiol actin that acts as a non-steroidal estrogen [64]. The different effects of in vivo administration of genistein are therefore not surprising. Thus, while Mohammadshahi et al. found a marked recovery in PON1 activity [33], Schrader et al. did not observe any such changes [62]. However, there are major differences between these two papers despite using the same animal model (rat), including dose (20 in the former vs. $1 \mathrm{mg} / \mathrm{kg}$ in the latter), length of administration (50 vs. 22 days), and presence or absence of a pathological condition decreasing PON1 activity. According to our comparison of dose and observed effect, this isolated compound may have a noticeable effect on PON1 in vivo (Table 2). The change induced by tea catechins is also remarkable. Thus, flavonoids are considered to be important agents for increasing PON1 activity.

Table 2. Effect of phenolic compounds on PON1 in different in vivo experimental settings.

\begin{tabular}{ccccc}
\hline Compound & Experimental Model & Dose & Effect & References \\
\hline $\begin{array}{c}\text { 3-(4-Hydroxyphenyl) } \\
\text { propionic acid }\end{array}$ & Rats fed a high-cholesterol diet & $1.35 \mathrm{mmol} / \mathrm{kg}$ & $\uparrow$ & {$[53]$} \\
Resveratrol & Apoe-deficient mice & $12 \mathrm{mg} / \mathrm{kg}$ & $\uparrow 75 \%$ & {$[56]$} \\
Flavonoids & & & \\
Naringenin & High-cholesterol-fed Sprague-Dawley rats & $4 \mathrm{mg} / \mathrm{kg}$ & $\uparrow 37 \%$ & {$[59]$} \\
Rutin & Wistar rats & $400 \mathrm{mg} / \mathrm{kg}$ & $\uparrow 17 \%$ & {$[60]$} \\
Quercetin & $\mathrm{HgCl}_{2}$ treated Wistar rats & $20 \mathrm{mg} / \mathrm{kg}$ & $\uparrow 20 \%$ & {$[28]$} \\
Genistein & Arthritic rats & $20 \mathrm{mg} / \mathrm{kg}$ & $\uparrow 230 \%$ & {$[33]$} \\
Tea catechins & Hemodialyzed patients & $6 \mathrm{mg} / \mathrm{kg}$ & $\uparrow 150 \%$ & {$[61]$} \\
Anthocyanins & Hypercholesterolemic subjects & $4 \mathrm{mg} / \mathrm{kg}$ & $\uparrow 22 \%$ & {$[65]$} \\
\hline
\end{tabular}

The effect of anthocyanins on HDL-PON1 activity and cholesterol efflux capacity was evaluated in hypercholesterolemic subjects, who received $160 \mathrm{mg}$ of anthocyanins twice daily for 24 weeks in a double-blind, randomized, placebo-controlled trial. Anthocyanin consumption significantly increased HDL cholesterol and HDL-PON1 activity, with negative correlations being established between the latter and HDL lipid hydroperoxides. Furthermore, a strongly positive correlation was noted between HDL-PON1 activity and cholesterol efflux capacity both before and after adjustment for HDL cholesterol and APOA1 in anthocyanin-treated subjects. These results indicate that HDL-PON1 activity might participate in the antioxidant and cholesterol efflux properties of HDL [65].

\section{Vitamins}

Two vitamins, namely $C$ and $E$, have received particular attention. Thus, supplementation with vitamin $\mathrm{C}$ provoked an increase in PON1 activity and a decrease in advanced glycation products and lipid hydroperoxide levels in hemodialysis patients. These findings provide further evidence that lipid peroxidation and impairment of the antioxidant system in the plasma of these patients may play a role in renal disease and suggest that evaluation of PON1 activity could represent a useful approach for monitoring antioxidant treatment and new dialysis therapies [66]. In a similar study, serum PON1 activity was found to decrease from preconception to labor in 35 women. A direct association between vitamin $\mathrm{C}$ intake and PON1 at week 32 was observed, suggesting that vitamin C supplementation in pregnant women deserves further attention [67]. However, a vitamin supplement (200-300 mg 
calcium, $15 \mathrm{mg}$ zinc, $17 \mathrm{mg}$ iron, $400 \mu \mathrm{g}$ folic acid, $400 \mathrm{IU}$ vitamin $\mathrm{D}, 70 \mathrm{mg}$ vitamin C, $3 \mathrm{mg}$ thiamine, $2 \mathrm{mg}$ riboflavin, $20 \mathrm{mg}$ niacin, $6 \mu \mathrm{g}$ vitamin B12, and $10 \mathrm{mg}$ vitamin E) had no effect on the oxidative stress status of healthy pregnant women [68]. When Begcevic et al. analyzed the effects of vitamin $\mathrm{C}$ and zinc ( $300 \mathrm{mg} /$ day) on serum PON1 activity in 31 healthy volunteers over four weeks, they observed a significant increase in PON1 activity in nonsmokers after the intervention [38]. Using the commercial preparation ALA nerv ${ }^{\circledR}$, which contains essential fatty acids, vitamins, and oligo-elements, Manolescu et al. reported an increase in PON1 lactonase activity in 28 post-acute stroke patients receiving two pills/day for two weeks [69].

Vitamin E supplementation increased the serum paraoxonase and arylesterase activities of propylthiouracil-induced hypothyroidism in male Sprague-Dawley rats [70]. This vitamin also recovered the decrease in PON1 induced by exercise in untrained dogs [71]. Likewise, oral supplementation of vitamin E (200 mg/day) prevented the exercise-induced decrease in PON1/Aryl esterase activity in basketball players [72]. This vitamin has been combined with other agents to improve PON1 properties. Thus, oral supplementation with vitamin E $(300 \mathrm{mg} / \mathrm{kg})$ and sodium selenite $(0.5 \mathrm{mg} / \mathrm{kg})$ once a day for four weeks in streptozotocin-induced diabetic rats restored PON1 activity to the levels observed in healthy animals [73]. The administration of $0.2 \%$ vitamin $\mathrm{E}$ together with $0.02 \%$ ferulic acid in Apoe-deficient mice also increased hepatic PON1 [74]. Other combinations, containing vitamin $C$, zinc gluconate, and selenium, have been prepared and tested in elite women athletes. Significant positive correlations between antioxidant defense and lipid status were found, with a significant positive correlation between PON1 activity toward paraoxon and LDL-cholesterol, but only before training and supplementation. Free-radical generation before and after training did not affect paroxonase activity, and no significant correlation was found with oxidative stress parameters $[75,76]$.

\section{Protein and Amino Acids}

Relatively little attention has been devoted to the influence of the quality of proteins or amino acids on PON1 activity. In this regard, commercial whey protein was found to improve PON1 activity in rats compared with casein [77]. Administration of the amino acid derivative L-carnitine recovered the exercise-induced decrease in PON1 in sedentary people [78], although the non-proteinogenic amino acid taurine was found to be more active. Thus, serum paraoxonase and arylesterase activities were increased in a dose-dependent manner in taurine-treated hypothyroid Sprague-Dawley rats, and taurine concentrations were positively correlated with enzyme activities [79].

\section{Dietary Lipids}

\subsection{Cholesterol Supplementation}

Administration of cholesterol (3.6 g/ kg/day) for three months decreased hepatic PON1 activity in Sprague-Dawley rats [80]. Similar results were obtained by our group using male Apoe-deficient mice and with lower cholesterol intakes $(1 \mathrm{~g} / \mathrm{kg} /$ day $)$. We also observed a selective sex response, with females being more resistant to the action of this compound [81].

\subsection{Polyunsaturated Fatty Acids}

A combination of red yeast rice and rice bran oil increased serum PON1 levels in male Sprague-Dawley rats compared to those receiving a hypercholesterolemic diet alone [17].

The ALA nerv ${ }^{\circledR}$ nutritional preparation, which contains linoleic acid, $\alpha$-lipoic acid, and gamma linoleic acid along with other vitamins and selenium, provoked a significant increase in PON1 lactonase activity when evaluated in post-acute stroke patients (two pills/day for two weeks) [69]. 


\section{Fish Oil}

The influence of supplementation with this oil on PON1 has been widely studied. Thus, an increase in serum PON1 activity associated with HDL lipid composition changes was observed in obese rats receiving $20 \%$ sardine byproduct oil [82], whereas dietary administration of $\omega-3$ fatty acids (EPA + DHA, 1.2:1) at doses of 0.3 or $1 \mathrm{~g} / \mathrm{kg}$ body weight for four weeks in rats decreased the activity of PON1. A similar decrease was observed in a postprandial approach involving fish oil supplementation in Balb/C mice associated with oxidative stress. This effect was corrected in PON1-transgenic mice, thereby suggesting a PON1 lipase-like activity on chylomicron triacylglycerols [10]. However, a higher dose of $\omega-3$ fatty acids resulted in a $45 \%$ increase in PON1 activity [83]. Hepatic PON1 activity significantly increased in fish-oil-treated rats [84].

In a double-blind randomized controlled trial carried out in 90 female patients with rheumatoid arthritis receiving $1 \mathrm{~g}$ of fish oil or a placebo in addition to conventional treatment, fish oil supplementation significantly increased PON1 activity [85]. Further positive evidence was obtained when comparing the HDL proteome before and after five weeks of a $\omega$-3 PUFA-supplemented diet in smoker subjects. In that study, Burillo et al. reported that the supplement increased PON1 protein, thereby suggesting a positive change in the functionality of the HDL molecule [86]. Contrary to these findings, in a randomized controlled trial, women with iron deficiency anemia randomly assigned to receive $500 \mathrm{mg}$ of DHA supplement or placebo with an iron tablet, once daily for 12 weeks, showed no significant differences in terms of serum PON1 concentration [87]. Four years ago, Whelan et al. reviewed the effect of stearidonic acid, a highly unsaturated (n-3) PUFA that is effectively metabolized to eicopentaenoic acid, and concluded that its administration is a favorable modulator of PON1 [88].

\subsection{Olive Oil and Coenzyme $Q_{10}$}

In subjects receiving $20 \mathrm{~mL}$ of extra virgin olive oil supplemented with 20 or $40 \mathrm{mg}$ of coenzyme Q10, a positive correlation was observed between concentration of the coenzyme in HDL and PON-1 activity, with a lower susceptibility of LDL to peroxidation also being found [89].

\subsection{Hydrocarbons}

Administration of squalene at a dose of $1 \mathrm{~g} / \mathrm{kg}$ for 11 weeks showed decreased reactive oxygen species in lipoprotein fractions irrespective of the animal background (wild-type, Apoa1-, and Apoe-deficient mice) and caused a specific increase in HDL-cholesterol levels, accompanied by an increase in PON1. The increases in HDL-PON1 resulted in decreased plasma malondialdehyde levels depending on the presence of apolipoprotein A1. The phenotype related to apolipoproteins A1 and E may be particularly relevant [90].

Astaxanthin is a carotenoid pigment present in crustaceans and salmon. In soccer players, there was a significant interaction between the effect of astaxanthin supplementation and training on PON1 activity. Thus, PON1 activity increased in the supplemented group after 90 days, as did the thiol content. As such, astaxanthin was proposed to improve PON1 activity by protecting free thiol groups against oxidative modification [91].

\section{Oligoelement Supplementation}

Two oligoelements, namely selenium and zinc, have received particular attention. With regard to the former, four months of selenium administration at $1 \mathrm{mg} / \mathrm{kg}$ diet improved the high-fat-diet-mediated reduction of serum PON1 enzyme activity and PON1 protein levels, with no changes in hepatic mRNA expression, in male Sprague-Dawley rats [92]. However, dietary supplementation with 1 or $3 \mathrm{mg}$ $\mathrm{Se} / \mathrm{kg}$ diet, with or without 250 or $750 \mathrm{mg}$ vitamin $\mathrm{E} / \mathrm{kg}$ diet, did not completely abolish the effects of $\mathrm{MeHg}$ as regards a reduction in PON1 activity [93]. Inclusion of ALA nerv ${ }^{\circledR}$, a nutritional supplement containing selenium (two pills/day for two weeks), resulted in a significant increase in PON lactonase activity when evaluated in post-acute stroke patients [69]. 
Zinc administration partially reversed the significant decrease in PON1 induced in rats by administration of carbon tetrachloride [94] and in mice by Schistosoma mansoni infection [95]. When tested in hemodialysis patients, a $100 \mathrm{mg} /$ day zinc supplementation for two months significantly increased serum levels of PON activity [96]. In 31 healthy volunteers exposed to commercially available preparations of vitamin C and zinc ( $300 \mathrm{mg}$ /day) for four weeks, Begcevic et al. also reported a significant increase in PON1 activity in nonsmokers after the intervention [38]. In contrast, mineral (15 mg zinc, $17 \mathrm{mg}$ iron) and vitamin supplementation failed to increase PON1 activity in pregnant women [68]. It has also been proposed that copper supplements may exert a protective effect on PON1, assuming that a copper deficiency decreases this enzyme [97]. The results suggest that the doses and/or exclusion criteria for subjects (smokers or non-smokers) and types of patients may be crucial in the outcome and should be carefully tested.

\section{Others}

Beta glucan supplementation increased PON1 activities in the brain and sciatic nerve of streptozotocin-induced diabetic rats [98]. Dietary supplements of symbiotics (Perfectin) and probiotics (Protexin) induced increased PON1 activity in White Leghorn chicken [99]. Supplementation with the commercial formulas Build-up (Nestle) and Maxijul (SHS Ltd.) for eight weeks failed to recover the decreased PON activity observed in frail elderly patients [100].

\section{Conditions Negatively Affecting PON1 Activity}

Several dietary supplements have been identified to have a negative influence on PON1 activity, including quercetin, vitamin, and amino acid supplementations, or at least in certain genetic backgrounds, animal models, or pathological conditions. As mentioned in Section 2, the response of PON1 activity to dietary supplements is modified by APOE gene polymorphisms. In this regard, the administration of a diet containing quercetin resulted in lower hepatic mRNA and protein levels of PON1 in APOE4 than in APOE3 transgenic mice [19]. Moreover, vitamin E supplementation in high-fat and -cholesterol diets significantly reduced serum PON1 activity in baboons [101]. Supplementation of the amino acid derivative betaine had no effect on plasma PON1 paraoxonase or arylesterase activities in hyperhomocysteinemic mice. However, betaine- and methionine-restricted diets decreased paraoxonase activity in this type of human patient [102].

\section{PON2}

Paraoxonase 2 (PON2), a member of the paraoxonase gene family, has been shown to protect macrophages against oxidative stress. Thus, incubation of J774A.1 macrophages with pomegranate juice $(0-50 \mu \mathrm{M}$ of total polyphenols) increased expression (mRNA, protein) and PON2 activity, and reduced macrophage oxidative status, in a dose-dependent manner. These effects could be attributed to punicalagin and gallic acid, which are the main phenolic components of this juice. The polyphenol-induced upregulation of PON2 was inhibited by using the peroxisome proliferator-activated receptor gamma (PPAR $\gamma$ ) inhibitor GW9662. Similarly, the PPAR $\gamma$ ligand rosiglitazone stimulated macrophage PON2 expression in a dose-dependent manner. Inhibition of AP-1 activation with SP600125 attenuated pomegranate juice-induced upregulation of PON2. Thus, the pomegranate juice stimulatory effect on macrophage PON2 expression was associated with activation of the transcription factors PPAR $\gamma$ and AP-1 [103]. Consumption of whole fruit juice and peels, either as a liquid or powder extract, resulted in a significant increase in PON2 lactonase activity in mice macrophages [50]. Another phenolic-rich plant has been tested as regards its ability to modulate PON2. Thus, in vitro incubation of THP-1 macrophages with yerba mate (Ilex paraguariensis) extract increased PON2 gene expression at concentrations ranging from 1 to $3 \mu \mathrm{mol} / \mathrm{L}$, whereas higher concentrations only increased the activity. Increased PON2 gene expression and activity were observed in the monocytes of healthy women $2 \mathrm{~h}$ after yerba mate consumption. However, when this extract 
was administered for seven days, the increase in gene expression was not reflected in the activity of either monocytes or monocyte-derived macrophages [104].

\section{PON3}

Despite having an important protective role against atherosclerosis, no studies have been found regarding dietary regulation of the third member of this family [6].

\section{Conclusions and Outlook}

A wide range of experimental evidence indicates that increasing PON1 and PON2 activity may decrease oxidative stress and contribute to delaying the outcome of chronic diseases or mitigating their impact on quality-of-life in patients. The search for plant extracts that are able to modulate these activities is a highly active field of research, as reflected in this review. Given the tremendous amount of work required to characterize planetary diversity in this regard, this field will undoubtedly last for many more years. Complete chemical characterization of these plant extracts is an urgent and demanding task as regards both identifying the target molecule and determining the matrix that protects the active component. High-throughput screening will need to be carried out in cell culture for obvious reasons of efficiency and animal welfare. To date, pomegranate juice has been well characterized, and Aronia melanocarpa extract seems very promising. The translation of these more promising findings into in vivo settings needs to be done carefully, paying special attention to formulation and stability, doses, length of administration, and selection of the experimental model. Once these aspects have been resolved, a wide range of formulations can be envisioned for nutraceuticals and functional foods to enhance the protective role of paraoxonases.

Acknowledgments: We thank Andrew Frankland for his assistance in manuscript editing. The work of this group was supported by grants from the Spanish Ministerio de Economía y Competitividad-European Regional Development Fund (2013-41651-R and 2016-75441-R) and the European Social Fund-Gobierno de Aragón (B-69). CIBER de Fisiopatología de la Obesidad y Nutrición (CIBEROBN) is an initiative of the Instituto de Salud Carlos III, Spain.

Author Contributions: José M. Lou-Bonafonte, Clara Gabás-Rivera, and María A. Navarro carried out the research and prepared the draft, and Jesús Osada supervised the work and draft and prepared the final version of the manuscript.

Conflicts of Interest: These authors declare no conflict of interest.

\section{References}

1. Libby, P.; Ridker, P.M.; Hansson, G.K. Progress and challenges in translating the biology of atherosclerosis. Nature 2011, 473, 317-325. [CrossRef] [PubMed]

2. Kingwell, B.A.; Chapman, M.J.; Kontush, A.; Miller, N.E. HDL-targeted therapies: Progress, failures and future. Nat. Rev. Drug Discov. 2014, 13, 445-464. [CrossRef] [PubMed]

3. Aviram, M.; Rosenblat, M.; Bisgaier, C.L.; Newton, R.S.; Primo-Parmo, S.L.; La Du, B.N. Paraoxonase inhibits high-density lipoprotein oxidation and preserves its functions. A possible peroxidative role for paraoxonase. J. Clin. Investig. 1998, 101, 1581-1590. [CrossRef] [PubMed]

4. Mackness, M.I.; Durrington, P.N.; Mackness, B. How high-density lipoprotein protects against the effects of lipid peroxidation. Curr. Opin. Lipidol. 2000, 11, 383-388. [CrossRef] [PubMed]

5. Kriska, T.; Marathe, G.K.; Schmidt, J.C.; McIntyre, T.M.; Girotti, A.W. Phospholipase action of platelet-activating factor acetylhydrolase, but not paraoxonase-1, on long fatty acyl chain phospholipid hydroperoxides. J. Biol. Chem. 2007, 282, 100-108. [CrossRef] [PubMed]

6. Furlong, C.E.; Marsillach, J.; Jarvik, G.P.; Costa, L.G. Paraoxonases-1, -2 and -3: What are their functions? Chem. Biol. Interact. 2016, 259, 51-62. [CrossRef] [PubMed]

7. Rosenblat, M.; Gaidukov, L.; Khersonsky, O.; Vaya, J.; Oren, R.; Tawfik, D.S.; Aviram, M. The catalytic histidine dyad of high density lipoprotein-associated serum paraoxonase-1 (PON1) is essential for PON1-mediated inhibition of low density lipoprotein oxidation and stimulation of macrophage cholesterol efflux. J. Biol. Chem. 2006, 281, 7657-7665. [CrossRef] [PubMed] 
8. Ben-David, M.; Elias, M.; Filippi, J.-J.; Duñach, E.; Silman, I.; Sussman, J.L.; Tawfik, D.S. Catalytic versatility and backups in enzyme active sites: The case of serum paraoxonase 1. J. Mol. Biol. 2012, 418, 181-196. [CrossRef] [PubMed]

9. Poeckel, D.; Funk, C.D. The 5-lipoxygenase/leukotriene pathway in preclinical models of cardiovascular disease. Cardiovasc. Res 2010, 86, 243-253. [CrossRef] [PubMed]

10. Fuhrman, B.; Volkova, N.; Aviram, M. Postprandial serum triacylglycerols and oxidative stress in mice after consumption of fish oil, soy oil or olive oil: Possible role for paraoxonase-1 triacylglycerol lipase-like activity. Nutrition 2006, 22, 922-930. [CrossRef] [PubMed]

11. Mackness, B.; Durrington, P.; McElduff, P.; Yarnell, J.; Azam, N.; Watt, M.; Mackness, M. Low paraoxonase activity predicts coronary events in the caerphilly prospective study. Circulation 2003, 107, 2775-2779. [CrossRef] [PubMed]

12. Mackness, M.; Mackness, B. Human paraoxonase-1 (PON1): Gene structure and expression, promiscuous activities and multiple physiological roles. Gene 2015, 567, 12-21. [CrossRef] [PubMed]

13. Shih, D.M.; Gu, L.; Xia, Y.-R.; Navab, M.; Li, W.-F.; Hama, S.; Castellani, L.W.; Furlong, C.E.; Costa, L.G.; Fogelman, A.M.; et al. Mice lacking serum paraoxonase are susceptible to organophosphate toxicity and atherosclerosis. Nature 1998, 394, 284-287. [PubMed]

14. Tward, A.; Xia, Y.-R.; Wang, X.-P.; Shi, Y.-S.; Park, C.; Castellani, L.W.; Lusis, A.J.; Shih, D.M. Decreased atherosclerotic lesion formation in human serum paraoxonase transgenic mice. Circulation 2002, 106, 484-490. [CrossRef] [PubMed]

15. Costa, L.G.; Giordano, G.; Furlong, C.E. Pharmacological and dietary modulators of paraoxonase 1 (PON1) activity and expression: The hunt goes on. Biochem. Pharmacol. 2011, 81, 337-344. [CrossRef] [PubMed]

16. Lou-Bonafonte, J.; Gabás-Rivera, C.; Navarro, M.; Osada, J. PON1 and mediterranean diet. Nutrients 2015, 7, 4068-4092. [CrossRef] [PubMed]

17. Govindarajan, S.; Vellingiri, K. Effect of red yeast rice and coconut, rice bran or sunflower oil combination in rats on hypercholesterolemic diet. J. Clin. Diagn. Res. 2016, 10, BF05-BF07. [CrossRef] [PubMed]

18. Moher, D.; Liberati, A.; Tetzlaff, J.; Altman, D.G. The PRISMA Group. Preferred reporting items for systematic reviews and meta-analyses: The prisma statement. PLoS Med. 2009, 6, e1000097. [CrossRef] [PubMed]

19. Boesch-Saadatmandi, C.; Niering, J.; Minihane, A.M.; Wiswedel, I.; Gardeman, A.; Wolffram, S.; Rimbach, G. Impact of apolipoprotein e genotype and dietary quercetin on paraoxonase 1 status in ApoE3 and ApoE4 transgenic mice. Atherosclerosis 2010, 211, 110-113. [CrossRef] [PubMed]

20. Dalgard, C.; Christiansen, L.; Jonung, T.; Mackness, M.I.; de Maat, M.P.; Horder, M. No influence of increased intake of orange and blackcurrant juices and dietary amounts of vitamin $\mathrm{E}$ on paraoxonase-1 activity in patients with peripheral arterial disease. Eur. J. Nutr. 2007, 46, 354-363. [CrossRef] [PubMed]

21. Park, S.A.; Choi, M.S.; Jung, U.J.; Kim, M.J.; Kim, D.J.; Park, H.M.; Park, Y.B.; Lee, M.K. Eucommia ulmoides oliver leaf extract increases endogenous antioxidant activity in type 2 diabetic mice. J. Med. Food 2006, 9, 474-479. [CrossRef] [PubMed]

22. Saha, A.; Mazumder, S. An aqueous extract of Murraya koenigii leaves induces paraoxonase 1 activity in streptozotocin induced diabetic mice. Food Funct. 2013, 4, 420-425. [CrossRef] [PubMed]

23. Kiyici, A.; Okudan, N.; Gokbel, H.; Belviranli, M. The effect of grape seed extracts on serum paraoxonase activities in streptozotocin-induced diabetic rats. J. Med. Food 2010, 13, 725-728. [CrossRef] [PubMed]

24. El-Beshbishy, H.A.; Singab, A.N.; Sinkkonen, J.; Pihlaja, K. Hypolipidemic and antioxidant effects of Morus alba L. (egyptian mulberry) root bark fractions supplementation in cholesterol-fed rats. Life Sci. 2006, 78, 2724-2733. [CrossRef] [PubMed]

25. Noll, C.; Hamelet, J.; Matulewicz, E.; Paul, J.L.; Delabar, J.M.; Janel, N. Effects of red wine polyphenolic compounds on paraoxonase-1 and lectin-like oxidized low-density lipoprotein receptor-1 in hyperhomocysteinemic mice. J. Nutr. Biochem. 2009, 20, 586-596. [CrossRef] [PubMed]

26. Farrell, N.; Norris, G.; Lee, S.G.; Chun, O.K.; Blesso, C.N. Anthocyanin-rich black elderberry extract improves markers of HDL function and reduces aortic cholesterol in hyperlipidemic mice. Food Funct. 2015, 6, 1278-1287. [CrossRef] [PubMed]

27. Kim, B.; Ku, C.S.; Pham, T.X.; Park, Y.; Martin, D.A.; Xie, L.; Taheri, R.; Lee, J.; Bolling, B.W. Aronia melanocarpa (chokeberry) polyphenol-rich extract improves antioxidant function and reduces total plasma cholesterol in apolipoprotein e knockout mice. Nutr. Res. 2013, 33, 406-413. [CrossRef] [PubMed] 
28. Jaiswal, N.; Rizvi, S.I. Onion extract (Allium cepa L.), quercetin and catechin up-regulate paraoxonase 1 activity with concomitant protection against low-density lipoprotein oxidation in male Wistar rats subjected to oxidative stress. J. Sci. Food Agric. 2014, 94, 2752-2757. [CrossRef] [PubMed]

29. Francik, R.; Krosniak, M.; Sanocka, I.; Barton, H.; Hebda, T.; Francik, S. Aronia melanocarpa treatment and antioxidant status in selected tissues in Wistar rats. Biomed. Res. Int. 2014, 2014, 457085. [CrossRef] [PubMed]

30. Francik, R.; Kryczyk, J.; Krosniak, M.; Berkoz, M.; Sanocka, I.; Francik, S. The neuroprotective effect of cornus mas on brain tissue of Wistar rats. Sci. World J. 2014, 2014, 847368. [CrossRef] [PubMed]

31. Nounou, H.A.; Deif, M.M.; Shalaby, M.A. Effect of flaxseed supplementation and exercise training on lipid profile, oxidative stress and inflammation in rats with myocardial ischemia. Lipids Health Dis. 2012, 11, 129. [CrossRef] [PubMed]

32. Caliskan, A.; Karahan, O.; Yazici, S.; Demirtas, S.; Guclu, O.; Tezcan, O.; Yavuz, C. Protective effects of ginseng extracts and common anti-aggregant drugs on ischaemia-reperfusion injury. Cardiovasc. J. Afr. 2015, 26, 222-226. [CrossRef] [PubMed]

33. Mohammadshahi, M.; Haidari, F.; Saei, A.A.; Rashidi, B.; Mahboob, S.; Rashidi, M.R. Soy protein, genistein, and daidzein improve serum paraoxonase activity and lipid profiles in rheumatoid arthritis in rats. J. Med. Food 2013, 16, 147-154. [CrossRef] [PubMed]

34. De Souza, M.O.; Silva, M.; Silva, M.E.; Oliveira Rde, P.; Pedrosa, M.L. Diet supplementation with acai (Euterpe oleracea Mart.) pulp improves biomarkers of oxidative stress and the serum lipid profile in rats. Nutrition 2010, 26, 804-810. [CrossRef] [PubMed]

35. Perez Mendez, O.; Garcia Hernandez, L. High-density lipoproteins (HDL) size and composition are modified in the rat by a diet supplemented with "Hass" avocado (Persea americana Miller). Arch. Cardiol. Mex. 2007, 77, 17-24. [PubMed]

36. Janeesh, P.A.; Abraham, A. Amelioration of cholesterol induced atherosclerosis by normalizing gene expression, cholesterol profile and antioxidant enzymes by Vigna unguiculata. Plant Foods Hum. Nutr. 2013, 68, 118-123. [CrossRef] [PubMed]

37. Menini, T.; Heck, C.; Schulze, J.; de Mejia, E.; Gugliucci, A. Protective action of Ilex paraguariensis extract against free radical inactivation of paraoxonase-1 in high-density lipoprotein. Planta Med. 2007, 73, 1141-1147. [CrossRef] [PubMed]

38. Begcevic, I.; Simundic, A.M.; Nikolac, N.; Dobrijevic, S.; Rajkovic, M.G.; Tesija-Kuna, A. Can cranberry extract and vitamin $C+Z n$ supplements affect the in vivo activity of paraoxonase 1, antioxidant potential, and lipid status? Clin. Lab. 2013, 59, 1053-1060. [PubMed]

39. Shidfar, F.; Rajab, A.; Rahideh, T.; Khandouzi, N.; Hosseini, S.; Shidfar, S. The effect of ginger (Zingiber officinale) on glycemic markers in patients with type 2 diabetes. J. Complement. Integr. Med. 2015, 12, 165-170. [CrossRef] [PubMed]

40. Qian, Q.; Qian, S.; Fan, P.; Huo, D.; Wang, S. Effect of salvia miltiorrhiza hydrophilic extract on antioxidant enzymes in diabetic patients with chronic heart disease: A randomized controlled trial. Phytother. Res. 2012, 26, 60-66. [CrossRef] [PubMed]

41. Ozdemir, B.; Ekbul, A.; Topal, N.B.; Sarandol, E.; Sag, S.; Baser, K.H.; Cordan, J.; Gullulu, S.; Tuncel, E.; Baran, I.; et al. Effects of Origanum onites on endothelial function and serum biochemical markers in hyperlipidaemic patients. J. Int. Med. Res. 2008, 36, 1326-1334. [CrossRef] [PubMed]

42. Cheng, C.C.; Wu, L.C.; Lai, J.M.; Chen, C.T.; Hsueh, C.M.; Hsu, S.L. Ethanol extract of Graptopetalum paraguayense upregulates paraoxonase 1 gene expression via an AKT/NF-kB-dependent pathway. Am. J. Chin. Med. 2012, 40, 357-372. [CrossRef] [PubMed]

43. Gugliucci, A.; Bastos, D.H. Chlorogenic acid protects paraoxonase 1 activity in high density lipoprotein from inactivation caused by physiological concentrations of hypochlorite. Fitoterapia 2009, 80, 138-142. [CrossRef] [PubMed]

44. Deakova, Z.; Orszaghova, Z.; Andrezalova, L.; Slezak, P.; Lehotay, J.; Muchova, J.; Burki, C.; Durackova, Z. Influence of oak wood polyphenols on cysteine, homocysteine and glutathione total levels and PON1 activities in human adult volunteers-A pilot study. Gen. Physiol. Biophys. 2015, 34, 73-80. [CrossRef] [PubMed]

45. Rosenblat, M.; Volkova, N.; Borochov-Neori, H.; Judeinstein, S.; Aviram, M. Anti-atherogenic properties of date vs. Pomegranate polyphenols: The benefits of the combination. Food Funct. 2015, 6, 1496-1509. [CrossRef] [PubMed] 
46. Aviram, M.; Rosenblat, M.; Gaitini, D.; Nitecki, S.; Hoffman, A.; Dornfeld, L.; Volkova, N.; Presser, D.; Attias, J.; Liker, H.; et al. Pomegranate juice consumption for 3 years by patients with carotid artery stenosis reduces common carotid intima-media thickness, blood pressure and LDL oxidation. Clin. Nutr. 2004, 23, 423-433. [CrossRef] [PubMed]

47. Rosenblat, M.; Hayek, T.; Aviram, M. Anti-oxidative effects of pomegranate juice (PJ) consumption by diabetic patients on serum and on macrophages. Atherosclerosis 2006, 187, 363-371. [CrossRef] [PubMed]

48. Balbir-Gurman, A.; Fuhrman, B.; Braun-Moscovici, Y.; Markovits, D.; Aviram, M. Consumption of pomegranate decreases serum oxidative stress and reduces disease activity in patients with active rheumatoid arthritis: A pilot study. Isr. Med. Assoc. J. 2011, 13, 474-479. [PubMed]

49. Fuhrman, B.; Volkova, N.; Aviram, M. Pomegranate juice polyphenols increase recombinant paraoxonase-1 binding to high-density lipoprotein: Studies in vitro and in diabetic patients. Nutrition 2010, 26, 359-366. [CrossRef] [PubMed]

50. Aviram, M.; Volkova, N.; Coleman, R.; Dreher, M.; Reddy, M.K.; Ferreira, D.; Rosenblat, M. Pomegranate phenolics from the peels, arils, and flowers are antiatherogenic: Studies in vivo in atherosclerotic apolipoprotein E-deficient $\left(\mathrm{E}^{0}\right)$ mice and in vitro in cultured macrophages and lipoproteins. J. Agric. Food Chem. 2008, 56, 1148-1157. [CrossRef] [PubMed]

51. Rock, W.; Rosenblat, M.; Miller-Lotan, R.; Levy, A.P.; Elias, M.; Aviram, M. Consumption of wonderful variety pomegranate juice and extract by diabetic patients increases paraoxonase 1 association with high-density lipoprotein and stimulates its catalytic activities. J. Agric. Food Chem. 2008, 56, 8704-8713. [CrossRef] [PubMed]

52. Wu, P.T.; Fitschen, P.J.; Kistler, B.M.; Jeong, J.H.; Chung, H.R.; Aviram, M.; Phillips, S.A.; Fernhall, B.; Wilund, K.R. Effects of pomegranate extract supplementation on cardiovascular risk factors and physical function in hemodialysis patients. J. Med. Food 2015, 18, 941-949. [CrossRef] [PubMed]

53. Lee, M.K.; Park, E.M.; Bok, S.H.; Jung, U.J.; Kim, J.Y.; Park, Y.B.; Huh, T.L.; Kwon, O.S.; Choi, M.S. Two cinnamate derivatives produce similar alteration in mRNA expression and activity of antioxidant enzymes in rats. J. Biochem. Mol. Toxicol. 2003, 17, 255-262. [CrossRef] [PubMed]

54. Schrader, C.; Schiborr, C.; Frank, J.; Rimbach, G. Curcumin induces paraoxonase 1 in cultured hepatocytes in vitro but not in mouse liver in vivo. Br. J. Nutr. 2011, 105, 167-170. [CrossRef] [PubMed]

55. Wagner, A.E.; Boesch-Saadatmandi, C.; Breckwoldt, D.; Schrader, C.; Schmelzer, C.; Doring, F.; Hashida, K.; Hori, O.; Matsugo, S.; Rimbach, G. Ascorbic acid partly antagonizes resveratrol mediated heme oxygenase-1 but not paraoxonase-1 induction in cultured hepatocytes-Role of the redox-regulated transcription factor Nrf2. BMC Complement. Altern. Med. 2011, 11, 1. [CrossRef] [PubMed]

56. Do, G.M.; Kwon, E.Y.; Kim, H.J.; Jeon, S.M.; Ha, T.Y.; Park, T.; Choi, M.S. Long-term effects of resveratrol supplementation on suppression of atherogenic lesion formation and cholesterol synthesis in ApoE-deficient mice. Biochem. Biophys. Res. Commun. 2008, 374, 55-59. [CrossRef] [PubMed]

57. Noll, C.; Hamelet, J.; Ducros, V.; Belin, N.; Paul, J.L.; Delabar, J.M.; Janel, N. Resveratrol supplementation worsen the dysregulation of genes involved in hepatic lipid homeostasis observed in hyperhomocysteinemic mice. Food Chem. Toxicol. 2009, 47, 230-236. [CrossRef] [PubMed]

58. Mariappan, D.; Winkler, J.; Parthiban, V.; Doss, M.X.; Hescheler, J.; Sachinidis, A. Dietary small molecules and large-scale gene expression studies: An experimental approach for understanding their beneficial effects on the development of malignant and non-malignant proliferative diseases. Curr. Med. Chem. 2006, 13, 1481-1489. [CrossRef] [PubMed]

59. Lee, M.K.; Bok, S.H.; Jeong, T.S.; Moon, S.S.; Lee, S.E.; Park, Y.B.; Choi, M.S. Supplementation of naringenin and its synthetic derivative alters antioxidant enzyme activities of erythrocyte and liver in high cholesterol-fed rats. Bioorg. Med. Chem. 2002, 10, 2239-2244. [CrossRef]

60. Kravchenko, L.V.; Avren'eva, L.I.; Aksenov, I.V.; Balakina, A.S.; Guseva, G.V.; Trusov, N.V. Effects of rutin on protective capacity in rats. Vopr. Pitan. 2015, 84, 22-30. [PubMed]

61. Hsu, S.P.; Wu, M.S.; Yang, C.C.; Huang, K.C.; Liou, S.Y.; Hsu, S.M.; Chien, C.T. Chronic green tea extract supplementation reduces hemodialysis-enhanced production of hydrogen peroxide and hypochlorous acid, atherosclerotic factors, and proinflammatory cytokines. Am. J. Clin. Nutr. 2007, 86, 1539-1547. [PubMed]

62. Schrader, C.; Ernst, I.M.; Sinnecker, H.; Soukup, S.T.; Kulling, S.E.; Rimbach, G. Genistein as a potential inducer of the anti-atherogenic enzyme paraoxonase-1: Studies in cultured hepatocytes in vitro and in rat liver in vivo. J. Cell. Mol. Med. 2012, 16, 2331-2341. [CrossRef] [PubMed] 
63. Oh, H.Y.; Kim, S.S.; Chung, H.Y.; Yoon, S. Isoflavone supplements exert hormonal and antioxidant effects in postmenopausal Korean women with diabetic retinopathy. J. Med. Food 2005, 8, 1-7. [CrossRef] [PubMed]

64. Setchell, K.D.R.; Clerici, C. Equol: History, chemistry, and formation. J. Nutr. 2010, 140, 1355S-1362S. [CrossRef] [PubMed]

65. Zhu, Y.; Huang, X.; Zhang, Y.; Wang, Y.; Liu, Y.; Sun, R.; Xia, M. Anthocyanin supplementation improves HDL-associated paraoxonase 1 activity and enhances cholesterol efflux capacity in subjects with hypercholesterolemia. J. Clin. Endocrinol. Metab. 2014, 99, 561-569. [CrossRef] [PubMed]

66. Ferretti, G.; Bacchetti, T.; Masciangelo, S.; Pallotta, G. Lipid peroxidation in hemodialysis patients: Effect of vitamin C supplementation. Clin. Biochem. 2008, 41, 381-386. [CrossRef] [PubMed]

67. Ferre, N.; Camps, J.; Fernandez-Ballart, J.; Arija, V.; Murphy, M.M.; Marsillach, J.; Joven, J. Longitudinal changes in serum paraoxonase-1 activity throughout normal pregnancy. Clin. Chem. Lab. Med. 2006, 44, 880-882. [CrossRef] [PubMed]

68. Ardalic, D.; Stefanovic, A.; Kotur-Stevuljevic, J.; Vujovic, A.; Spasic, S.; Spasojevic-Kaliomanvska, V.; Jelic-Ivanovic, Z.; Mandic-Markovic, V.; Mikovic, Z.; Cerovic, N. The influence of maternal smoking habits before pregnancy and antioxidative supplementation during pregnancy on oxidative stress status in a non-complicated pregnancy. Adv. Clin. Exp. Med. 2014, 23, 575-583. [CrossRef] [PubMed]

69. Manolescu, B.N.; Berteanu, M.; Cinteza, D. Effect of the nutritional supplement ALAnerv ${ }^{\circledR}$ on the serum PON1 activity in post-acute stroke patients. Pharmacol. Rep. 2013, 65, 743-750. [CrossRef]

70. Sarandol, E.; Tas, S.; Dirican, M.; Serdar, Z. Oxidative stress and serum paraoxonase activity in experimental hypothyroidism: Effect of vitamin E supplementation. Cell Biochem. Funct. 2005, 23, 1-8. [CrossRef] [PubMed]

71. Motta, S.; Letellier, C.; Ropert, M.; Motta, C.; Thiebault, J.J. Protecting effect of vitamin E supplementation on submaximal exercise-induced oxidative stress in sedentary dogs as assessed by erythrocyte membrane fluidity and paraoxonase-1 activity. Vet. J. 2009, 181, 288-295. [CrossRef] [PubMed]

72. Tsakiris, S.; Karikas, G.A.; Parthimos, T.; Tsakiris, T.; Bakogiannis, C.; Schulpis, K.H. $\alpha$-Tocopherol supplementation prevents the exercise-induced reduction of serum paraoxonase 1/arylesterase activities in healthy individuals. Eur. J. Clin. Nutr. 2009, 63, 215-221. [CrossRef] [PubMed]

73. Ghaffari, T.; Nouri, M.; Saei, A.A.; Rashidi, M.R. Aldehyde and xanthine oxidase activities in tissues of streptozotocin-induced diabetic rats: Effects of vitamin E and selenium supplementation. Biol. Trace Elem. Res. 2012, 147, 217-225. [CrossRef] [PubMed]

74. Kwon, E.Y.; Cho, Y.Y.; Do, G.M.; Kim, H.J.; Jeon, S.M.; Park, Y.B.; Lee, M.K.; Min, T.S.; Choi, M.S. Actions of ferulic acid and vitamin $\mathrm{E}$ on prevention of hypercholesterolemia and atherogenic lesion formation in apolipoprotein E-deficient mice. J. Med. Food 2009, 12, 996-1003. [CrossRef] [PubMed]

75. Martinovic, J.; Dopsaj, V.; Kotur-Stevuljevic, J.; Dopsaj, M.; Vujovic, A.; Stefanovic, A.; Nesic, G. Oxidative stress biomarker monitoring in elite women volleyball athletes during a 6-week training period. J. Strength Cond. Res. 2011, 25, 1360-1367. [CrossRef] [PubMed]

76. Martinovic, J.; Dopsaj, V.; Kotur-Stevuljevic, J.; Dopsaj, M.; Vujovic, A.; Stefanovic, A.; Nesic, G. Proxidant antioxidant balance in supplemented elite female volleyball athletes during a six week training period. J. Sports Med. Phys. Fit. 2011, 51, 145-152.

77. Haraguchi, F.K.; Pedrosa, M.L.; Paula, H.; Santos, R.C.; Silva, M.E. Evaluation of biological and biochemical quality of whey protein. J. Med. Food 2010, 13, 1505-1509. [CrossRef] [PubMed]

78. Siktar, E.; Ekinci, D.; Siktar, E.; Beydemir, S.; Gulcin, I.; Gunay, M. Protective role of L-carnitine supplementation against exhaustive exercise induced oxidative stress in rats. Eur. J. Pharmacol. 2011, 668, 407-413. [CrossRef] [PubMed]

79. Dirican, M.; Tas, S.; Sarandol, E. High-dose taurine supplementation increases serum paraoxonase and arylesterase activities in experimental hypothyroidism. Clin. Exp. Pharmacol. Physiol. 2007, 34, 833-837. [CrossRef] [PubMed]

80. Durak, I.; Ozbek, H.; Devrim, E.; Karagenc, N.; Erguder, I.B. Effects of cholesterol supplementation on antioxidant enzyme activities in rat hepatic tissues: Possible implications of hepatic paraoxonase in atherogenesis. Nutr. Metab. Cardiovasc. Dis. 2004, 14, 211-214. [CrossRef] 
81. Acin, S.; Navarro, M.A.; Carnicer, R.; Arbones-Mainar, J.M.; Guzman, M.A.; Arnal, C.; Beltran, G.; Uceda, M.; Maeda, N.; Osada, J. Dietary cholesterol suppresses the ability of olive oil to delay the development of atherosclerotic lesions in apolipoprotein E knockout mice. Atherosclerosis 2005, 182, 17-28. [CrossRef] [PubMed]

82. Boukhari, N.; Taleb-Senouci, D.; Chabane, F.Z.; Besbes, M.; Lamri-Senhadji, M.Y. Fish by-products oil corrects dyslipidemia, improves reverse cholesterol transport and stimulates paraoxonase-1 activity in obese rat. Ann. Cardiol. Angeiol. 2013, 62, 149-154. [CrossRef] [PubMed]

83. Kravchenko, L.V.; Aksenov, I.V.; Avren'eva, L.I.; Beketova, N.A.; Trusov, N.V.; Guseva, G.V. Effects of $\omega-3$ polyunsaturated fatty acids on antioxidant capacity in rats. Vopr. Pitan. 2013, 82, 4-9. [PubMed]

84. Popovic, T.; Borozan, S.; Arsic, A.; Martacic, J.D.; Vucic, V.; Trbovic, A.; Mandic, L.; Glibetic, M. Fish oil supplementation improved liver phospholipids fatty acid composition and parameters of oxidative stress in male Wistar rats. J. Anim. Physiol. Anim. Nutr. 2012, 96, 1020-1029. [CrossRef] [PubMed]

85. Ghorbanihaghjo, A.; Kolahi, S.; Seifirad, S.; Rashtchizadeh, N.; Argani, H.; Hajialilo, M.; Khabazi, A.; Alizadeh, S.; Bahreini, E. Effect of fish oil supplements on serum paraoxonase activity in female patients with rheumatoid arthritis: A double-blind randomized controlled trial. Arch. Iran. Med. 2012, 15, 549-552. [PubMed]

86. Burillo, E.; Mateo-Gallego, R.; Cenarro, A.; Fiddyment, S.; Bea, A.M.; Jorge, I.; Vazquez, J.; Civeira, F. Beneficial effects of $\omega-3$ fatty acids in the proteome of high-density lipoprotein proteome. Lipids Health Dis. 2012, 11, 116. [CrossRef] [PubMed]

87. Shidfar, F.; Amani, S.; Vafa, M.; Shekarriz, R.; Hosseini, S.; Shidfar, S.; Eshraghian, M.; Mousavi, S.N. Effects of iron supplementation with and without docosahexaenoic acid on the cardiovascular disease risk based on paraoxonase-1, hs-CRP, and ApoB/Apoa-I ratio in women with iron deficiency anemia. Biol. Trace Elem. Res. 2016, 169, 34-40. [CrossRef] [PubMed]

88. Whelan, J.; Gouffon, J.; Zhao, Y. Effects of dietary stearidonic acid on biomarkers of lipid metabolism. J. Nutr. 2012, 142, 630S-634S. [CrossRef] [PubMed]

89. Bruge, F.; Bacchetti, T.; Principi, F.; Scarpa, E.S.; Littarru, G.P.; Tiano, L. Olive oil supplemented with coenzyme $\mathrm{Q}_{10}$ : Effect on plasma and lipoprotein oxidative status. Biofactors 2012, 38, 249-256. [CrossRef] [PubMed]

90. Gabas-Rivera, C.; Barranquero, C.; Martinez-Beamonte, R.; Navarro, M.A.; Surra, J.C.; Osada, J. Dietary squalene increases high density lipoprotein-cholesterol and paraoxonase 1 and decreases oxidative stress in mice. PLoS ONE 2014, 9, e104224. [CrossRef] [PubMed]

91. Baralic, I.; Djordjevic, B.; Dikic, N.; Kotur-Stevuljevic, J.; Spasic, S.; Jelic-Ivanovic, Z.; Radivojevic, N.; Andjelkovic, M.; Pejic, S. Effect of astaxanthin supplementation on paraoxonase 1 activities and oxidative stress status in young soccer players. Phytother. Res. 2013, 27, 1536-1542. [CrossRef] [PubMed]

92. Kaur, H.D.; Bansal, M.P. Studies on HDL associated enzymes under experimental hypercholesterolemia: Possible modulation on selenium supplementation. Lipids Health Dis. 2009, 8, 55. [CrossRef] [PubMed]

93. Jin, X.; Hidiroglou, N.; Lok, E.; Taylor, M.; Kapal, K.; Ross, N.; Sarafin, K.; Lau, A.; de Souza, A.; Chan, H.M.; et al. Dietary selenium $(\mathrm{Se})$ and vitamin $\mathrm{E}\left(\mathrm{V}_{\mathrm{E}}\right)$ supplementation modulated methylmercury-mediated changes in markers of cardiovascular diseases in rats. Cardiovasc. Toxicol. 2012, 12, 10-24. [CrossRef] [PubMed]

94. Ferre, N.; Camps, J.; Cabre, M.; Paul, A.; Joven, J. Hepatic paraoxonase activity alterations and free radical production in rats with experimental cirrhosis. Metabolism 2001, 50, 997-1000. [PubMed]

95. Helmy, M.M.; Mahmoud, S.S.; Fahmy, Z.H. Schistosoma mansoni: Effect of dietary zinc supplement on egg granuloma in Swiss mice treated with praziqantel. Exp. Parasitol. 2009, 122, 310-317. [CrossRef] [PubMed]

96. Rahimi-Ardabili, B.; Argani, H.; Ghorbanihaghjo, A.; Rashtchizadeh, N.; Naghavi-Behzad, M.; Ghorashi, S.; Nezami, N. Paraoxonase enzyme activity is enhanced by zinc supplementation in hemodialysis patients. Ren. Fail. 2012, 34, 1123-1128. [CrossRef] [PubMed]

97. Klevay, L.M. Ischemic heart disease as deficiency disease. Cell. Mol. Biol. 2004, 50, 877-884. [PubMed]

98. Alp, H.; Varol, S.; Celik, M.M.; Altas, M.; Evliyaoglu, O.; Tokgoz, O.; Tanriverdi, M.H.; Uzar, E. Protective effects of $\beta$-glucan and gliclazide on brain tissue and sciatic nerve of diabetic rats induced by streptozosin. Exp. Diabetes Res. 2012, 2012, 230342. [CrossRef] [PubMed]

99. Anwar, H.; Rahman, Z.U.; Javed, I.; Muhammad, F. Effect of protein, probiotic, and symbiotic supplementation on serum biological health markers of molted layers. Poult. Sci. 2012, 91, 2606-2613. [CrossRef] [PubMed] 
100. Summerbell, J.; Wynne, H.; Hankey, C.R.; Williams, F.M. The effect of age and frailty upon blood esterase activities and their response to dietary supplementation. Br. J. Clin. Pharmacol. 1993, 36, 399-404. [CrossRef] [PubMed]

101. Rainwater, D.L.; Mahaney, M.C.; VandeBerg, J.L.; Wang, X.L. Vitamin E dietary supplementation significantly affects multiple risk factors for cardiovascular disease in baboons. Am. J. Clin. Nutr. 2007, 86, 597-603. [PubMed]

102. Jiang, H.; Stabler, S.P.; Allen, R.H.; Maclean, K.N. Altered expression of apoA-I, apoA-IV and PON-1 activity in CBS deficient homocystinuria in the presence and absence of treatment: Possible implications for cardiovascular outcomes. Mol. Genet. Metab. 2012, 107, 55-65. [CrossRef] [PubMed]

103. Shiner, M.; Fuhrman, B.; Aviram, M. Macrophage paraoxonase 2 (PON2) expression is up-regulated by pomegranate juice phenolic anti-oxidants via PPAR $\gamma$ and AP-1 pathway activation. Atherosclerosis 2007, 195, 313-321. [CrossRef] [PubMed]

104. Fernandes, E.S.; Machado Mde, O.; Becker, A.M.; de Andrade, F.; Maraschin, M.; da Silva, E.L. Yerba mate (Ilex paraguariensis) enhances the gene modulation and activity of paraoxonase-2: In vitro and in vivo studies. Nutrition 2012, 28, 1157-1164. [CrossRef] [PubMed]

(C) 2017 by the authors; licensee MDPI, Basel, Switzerland. This article is an open access article distributed under the terms and conditions of the Creative Commons Attribution (CC BY) license (http:/ / creativecommons.org/licenses/by/4.0/). 